\title{
A new learning and skills landscape? The central role of the Learning and Skills Council
}

Frank Coffield, Richard Steer, Ann Hodgson, Ken Spours, Sheila Edward and lan Finlay

This is the first paper from a project which is part of the Economic and Social Research Council's Programme of research into "Teaching and Learning". The project, entitled "The Impact of Policy on Learning and Inclusion in the New Learning and Skills Sector", explores what impact the efforts to create a single learning and skills system (LSS) are having on teaching, learning, assessment and inclusion for three marginalised groups of post-16 learners. Drawing primarily on policy documents and 62 in-depth interviews with national, regional and local policymakers in England, the paper points to a complex, confusing and constantly changing landscape; in particular, it deals with the formation, early years and recent reorganisation of the Learning and Skills Council (LSC), its roles, relations with Government, its rather limited power, its partnerships and likely futures.

While the formation of a more unified LSS is broadly seen as a necessary step in overcoming the fragmentation and inequalities of the previous post-16 sector, interviewees also highlighted problems, some of which may not simply abate with the passing of time. Political expectations of change are high, but the LSC and its partners are expected to carry through 'transformational' strategies without the necessary 'tools for the job'. In addition, some features of the LSS policy landscape still remain unreformed or need to be reorganised. The LSC and its partners are at the receiving end of a series of policy drivers (eg planning, funding, targets, inspection and initiatives) that may have partial or even perverse effects on the groups of marginalised learners we are studying.

\section{Introduction}

This Government has taken post-16 learning more seriously than previous administrations by allocating substantial funding, establishing new structures and creating a national strategy. The Learning and Skills Council (LSC), established in 2001, was an attempt to bring together, for the first time into a single learning and skills sector, a wide range of learning opportunities in further education, community and adult learning, work-based training for young people and workforce development for adults. The main function of the LSC was laid down by Government as 'ensuring that high quality post-16 provision is available to meet the needs of employers, individuals and communities' (DfEE, 1999:23). A new system of planning, funding and regulating post16 education and training, excluding higher education ${ }^{1}$, is slowly being created and the significance of the LSC can in part be judged by its budget of $£ 8,674,103,000$ for 200405, which, according to Ramsden et al (2004:401) accounts for approximately a third of the DfES's total budget for that year. The post-16 learning sector also consists of 6 million learners; including 1.2 million 15 and16 year olds on work experience every year; 500,000 Modern Apprentices and NVQ learners, around 500,000 teachers, tutors and trainers; more than 5,000 learning providers; at least 4,000 vocational qualifications; more than 400 Further Education (FE) Colleges; 114 recognised Awarding Bodies and 101 Local Learning Partnerships. This veritable mountain of purposeful learning remains largely unresearched and invisible to the British public. 
David Blunkett, the then Secretary of State for Education and Employment, described the creation of the LSC as 'the most significant and far reaching reform ever enacted to post-16 learning in this country. For the first time, the planning and funding of all post-compulsory learning below higher education will be integrated'; the structural change was to be 'both radical and enduring' (Blunkett, 2000:1). Our research project is funded by the Economic and Social Research Council's Teaching and Learning Research Programme ${ }^{2}$ (TLRP) to study the impact of the new LSS and national policy steering mechanisms on teaching, learning and assessment (TLA) and on inclusion. In particular, during the three years of the Project (January 2004 to March 2007), we are focussing on three groups of learners who have not traditionally been served well by the English education and training system but are principal target groups for the LSC unemployed adults on community based basic skills courses, adult employees in workforce development and younger learners on Level 1 and 2 courses in FE colleges.

This paper ${ }^{3}$, which is necessarily selective, concentrates on the past, present and future of the LSC, because of its role as the leading partner in the new LSS, and ends by raising a number of issues for the future development of the LSS and implications for TLA. It draws on the following different types of data:

- a documentary analysis of 136 central policy texts from 1998 to 2004 which we have catalogued and are studying;

- 67 interviews with officials from the key organisations at national, regional and local levels, including officials from the Department for Education and Skills (DfES), LSC, Local Learning and Skills Councils (LLSCs), Regional Development Agencies (RDAs), the Adult Learning Inspectorate (ALI), Local Learning Partnerships, Local Education Authorities (LEAs) as well as individuals from awarding bodies and independent policy research units. This paper is based on the first 62 of these interviews to be conducted, transcribed, checked and analysed;

- a first round of visits to 24 learning sites (12 in the North East and 12 in London) in FE Colleges, Adult and Community Learning Centres (ACL), and in Work Based Learning (WBL), which have been analysed; in each site we interviewed learners, tutors and managers;

- two research seminars (one held in Newcastle and the other in London), where our emerging ideas and our first paper were challenged and improved by national, regional and local policy-makers, practitioners and academics specialising in post-16 learning. The opportunity to gather further data was also taken at these events by, for example, asking 
participants to identify and then debate what they saw as the strengths and weakness of the Learning and Skills Sector.

Triangulation of our data therefore takes place at a number of levels: within each interview which is conducted by two researchers; within each research team (one in Newcastle, one in London); within the Project as a whole (when the data from the Newcastle and London are compared when the teams meet twice a term); between the Newcastle and London teams and national policy-makers, officials and local practitioners in London; and between the London and Newcastle teams and regional and local policy-makers, officials and practitioners in the North East. We also compare different levels of data - individual, institutional, sub-regional, regional, national and European. Our research seminars also bring together senior policy-makers from the DfES and LSC with local practitioners from FE Colleges, ACL Centres and WBL sites, enabling us to learn from the debates between the two groups, which have few, if any, such opportunities for discussion. We also wish to acknowledge the help provided by academic colleagues when an earlier draft of this paper was discussed at the annual conference of the TLRP at Cardiff in November, 2004.

This article has the specific task of describing systematically our initial findings on the role of the LSC within the learning and skills sector, but the project as a whole is committed to understanding the attempt to develop a coherent learning and skills system within a theoretical framework. We can, however, do little more here than indicate our views of theory which are in part drawn from the work of Basil Bernstein and Seymour Sarason. We agree with the former that the value of theory often consists in 'creating new empirical problems of some importance' (1996:100), and from the latter we accept that theory is 'a necessary myth that we construct to understand something we understand incompletely' (1990:123).

In this project we are both testing theory relevant to our main themes and also seeking to produce new theory. For example, the theoretical ideas being produced by Phil Hodkinson and his colleagues in the TLRP project on 'Transforming Learning Cultures in FE' will be explored empirically in the light of our data. Bernstein's theories about the relations between education and democracy are also crucial for us; for instance, his intriguing speculations about the interactions between structural conditions and pedagogies that create particular practices of inclusion and exclusion; the 'acoustic' of FE Colleges (i.e. whose voice is heard?); the democratic rights of all learners to individual enhancement, to social, intellectual, cultural and personal inclusion, and to participate in the political life of the institutions they attend. The great virtue of Bernstein's theory for our project, however, is that it shows how connections 
can be made between the macro structures of power and control, the meso level where institutions and agencies interpret national strategies and initiatives, and the micro processes of teaching and learning in particular classrooms.

As well as examining the current working of the Learning and Skill sector and detailing its many strengths as well as very obvious flaws, we also intend to produce a new theory about what an inclusive and effective learning and skills system would look like. At present we have only the barest outline of such a system, but we shall flesh that out by sharpening our ideas against the data we are collecting and against the tentative notions being produced by other specialists in the field.

Such a project as ours also needs some explicit theory of the state, social policy and change. So far our evidence fits well with Gramsci's idea of the state as passing through a series of 'unstable equilibria', which are well characterised by Clarke and Newman as 'temporary settlements and accommodations', where both the external conditions and internal relationships 'are contradictory and contested, creating instabilities' (1997:140-1). Associated with the political dominance of New Right ideas, the reconstructed welfare state has become more centralised and reliant on mechanisms such as contracting relationships (Ainley, 1998) and 'arms length' agencies to oversee the spending of public money (Skelcher, 1998). Janet Newman in a later article neatly summarized the new discourse of 'modern management':

- as being concerned not just about 'short-term efficiency but about longer-term effectiveness';

- as a 'set of tools and techniques' to meet policy outcomes, and

- as matching the political goal of 'joined-up government' with the 'managerial techniques of building partnerships and strategic alliances' (2000:47).

Her analysis of New Labour's use of modernization as a means of reforming all public services seeks to understand the transformation of social welfare since the 1980s, but it is also particularly apt for our study of the post-compulsory learning and skills sector. She deconstructs, for instance, such narratives as the cascading imperatives to change; innovation interpreted as the need for continuous improvement by autonomous institutions, which are at the same time hemmed in by prescriptive lists of changes laid down by government; decentralization which brings with it the strengthening of central controls; an espousal of partnership which ignores the intractable politics of inter- and intra- organisational collaboration'; and the rhetoric of participation which fails to specify 'who is to participate, at what level of decision making, and on whose terms' (2000:54 and 56). We shall use her incisive approach in 
our own attempt to explore to what extent the existing learning and skills sector exhibits features of the new managerialism and to specify what an effective and inclusive learning and skills system could look like.

The rest of this paper discusses the reasons for establishing the LSC; the merger which brought it into being; its structure, recent changes and regionalisation; its roles and responsibilities; its relations with the DfES and Government; the issue of power; its partnerships and relationships; policy levers and drivers and their implications for teaching, learning and assessment; its likely futures; and some tentative conclusions about the LSC's achievements and challenges.

\section{Why was the LSC thought necessary?}

When the new Labour Government came to power in May 1997, it inherited a diverse array of activities and organisations responsible for post-compulsory education and training apart from higher education:

- the Further Education Funding Council (FEFC) which funded and inspected FE Colleges;

- the 72 Training and Enterprise Councils (TECs) in England which organised Government funded training and workforce development alongside other enterprise activities;

- School Sixth Forms, funded by LEAs;

- Adult and Community Learning run by LEAs and other voluntary and community organisations.

In terms of new policy for lifelong learning all the new Government had to build on was a pamphlet from the previous Conservative administration, entitled Lifelong Learning: a policy framework, which contained no new ideas and no proposals for legislation (DfEE: 1996).

While the new Labour Government had a strong focus on lifelong learning based both on Labour Party documents created in opposition (eg Labour Party 1996a; 1996b) and on its early Green Paper The Learning Age (DfEE 1998), it did not have plans for large-scale structural change. It began, however, to see a case for structural change because of the weaknesses it perceived in funding and planning (eg the TECs had 72 different funding and planning systems); and in inspection and quality control (eg there were three separate inspectorates operating in the same area: FEFC, Office for 
Standards Education (OFSTED) and the Training Standards Council). The White Paper, Learning to Succeed: a new framework for post-16 learning, published in 1999, summarised the arguments for change thus:

'There is too much duplication, confusion and bureaucracy in the current system. Too little money actually reaches learners and employers, too much is tied up in bureaucracy. There is an absence of effective coordination or strategic planning. The system has insufficient focus on skill and employer needs at national, regional and local levels. The system lacks innovation and flexibility, and there needs to be more collaboration and co-operation to ensure higher standards and the right range of choices' (DfES, 1999:21).

Felstead and Unwin analysed in detail the funding principles of the TECs and of the FEFC and found that, with the TECs, the emphasis on output-related funding put 'great pressure on training providers to cut corners and even manufacture outcomes (qualifications or jobs)' (2001:101). On the other hand, the FEFC's funding system drove the Colleges to recruit particular types of students (eg full-timers on one or two year courses). More seriously still, however, both funding systems supported provision which did not 'necessarily meet quality standards or the skills agenda at the local, regional or national level' (2001:109). Moreover, there were a number of specific problems with the operation of the TECs that made them vulnerable following the change of administration in 1997, principally 'their failure to spend reserves on local initiatives, to actively pursue improvements in the performance of their sub-contractors, or to take a proactive role in improving efficiency through streamlining administration' (Tabor, 2004:30).

The Bureaucracy Task Force similarly pointed out that the LSC had 'inherited a funding methodology which was widely recognised to be over-complex and bureaucratic. Its operation of 'clawback' was a significant contributor to the financial insecurity and instability of some providers' (2004:8). These criticisms, widely acknowledged within the sector to have been accurate at the time, can in their turn now become the criteria by which to judge the new structural arrangements.

Some of our interviewees widened the attack upon the previous system. One official, for example, admonished the TECs for 'creaming off' funds from Government training programmes to resource their own initiatives; another thought the general quality of the training TECs organised was poor and that some had abused their independence. With regard to the FEFC, 'as the name implies, it was a funding body 
[with] no real focus on what was delivered'. For Leisha Fullick, a founding member of the LSC, the FEFC's 'obsession with audit trails created a new, but equally burdensome, bureaucratic quagmire to some of those it had cleared away. Its rush for growth through franchising led some colleges into disaster from which a few never recovered, and many others still feel the consequences' (2004:15). The LSC's inheritance was, therefore, bleak: it was bequeathed the admittedly chaotic arrangements of three different funding and administrative systems for school sixth forms, FE Colleges and training agencies' (Ainley, 2000:586).

\section{The Merger}

After only four years it is already being forgotten how complicated the transition to the new arrangements was in 2001. For example, the 72 TECs, all independent companies employing staff on different terms and conditions, had to be wound up. Moreover, the TECs employed around 10,000 staff, but just over 5,000 were transferred to the LSC, and this constituted the first major cut in staffing. For one of the key participants, it was more of a 'multi-merger ... with twelve or thirteen computer systems to integrate'. The budget, he added, was huge, 'came in 42 separate blocks ... but we got it down to six'.

In addition to these practical difficulties, the LSC experienced the cultural challenge of merging very different types of organisation: the FEFC was widely regarded as highly centralised and bureaucratic, while the TECs were considered to be more entrepreneurial and autonomous ... 'I mean [the TECs were] on the other side of the management spectrum in a way. I mean, they'd gone off and done their own thing'.

The LSC was being established at the very same time as the Government was receiving a bad press over the escalating costs of the Millennium Dome in Greenwich ${ }^{4}$ and the LSC was very aware that it needed to succeed. One official summarised the internal feelings within the LSC about the merger: 'It was technically and managerially a very difficult job and it did take about twelve, eighteen months ... But it didn't collapse, we did pay everybody and all the basics were taken care of. And if they'd gone wrong, there were a host of people sitting round with rifles loaded and aimed who, you know, didn't want the LSC to succeed'.

\section{Structure, Recent Changes and Regionalisation}

The Learning and Skills Act 2000 created the LSC as a single, non-departmental public body with 47 local LSCs organised on a sub-regional basis. Some of our interviewees thought that the successful launch of this new organisation in April 2001 owed much to the enthusiasm of three Ministers in the DfEE at the time: the Secretary of State, David 
Blunkett; the Minister of State for Further and Higher Education, Tessa Blackstone; and the Parliamentary Under Secretary of State for Lifelong Learning, Malcolm Wicks. After the General Election of 2001, however, when the LSC was only one month old, all three were transferred to other Ministries and their successors turned out to be less interested in the cause of reforming post-16 learning: 'so we were pretty lonely' was the verdict of one LSC official.

From the inception of the LSC, the Government had high expectations of the new organisation. In a 20 page remit letter, which David Blunkett sent to the LSC in November 2000, the Secretary of State charged the new body with drawing up a strategy both to meet the post-16 National Learning Targets and to enhance equal opportunities. He also added four wider objectives: to encourage young people to stay on in learning; to increase demand for learning by adults; to maximise the contribution of education and training to economic performance; and to raise standards. For the first time a public body was also given the statutory duty to encourage participation in learning.

These high political expectations of the LSC have continued. Each of the annual remit and grant letters has added to the LSC's initial objectives and has provided more detailed targets and new areas of work. Moreover, the policy landscape in this area has been constantly changing. Between 2001 and 2003 there were no less than seven major policy documents that fundamentally involved the LSC and, in effect, broadened its remit:

- The Skills for Life Strategy (DfEE 2001)

- 14-19: Extending Opportunities, Raising Standards (DfES 2002a)

- $\quad$ Success for All (DfES 2002b)

- $\quad$ The Future of Higher Education (DfES 2003a)

- 14-19: Opportunity and Excellence (DfES 2003b)

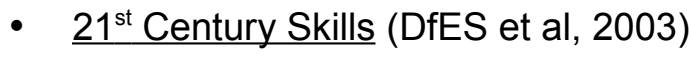

- Every Child Matters (HMT, 2003)

One official commented: 'You don't have time to read them, let alone to act on them'. Initially, the National LSC Council comprised 16 members representing post-16 providers, business, unions, higher education and LEAs; it was also advised by two statutory committees, one responsible for adults and the other for young people. At the local level, there were 47 local councils of between 12 and 16 members, each headed by an executive director, although internally structured in different ways. One official 
tried to capture what he, but only he, considered to be the 'unique' structure of the LSC: 'There's no other organisation in the UK which has this kind of national, somewhat regional, but very local [remit] and still tries to be one organisation'.

From the beginning, the LSC suffered from a conflict of expectations and values between those of the Chairman, Bryan Sanderson, who came from the business sector (BP) and favoured a small central team, and those of the senior management team, headed by John Harwood, who came predominantly from the public sector and who wanted a more inclusive approach to decision-making. So the potential for conflicts over values, management style and the relationship between the National LSC and its local arms was built into the structure from the outset.

In October 2003, after only two and a half years of operation, the LSC appointed a new Chief Executive, Mark Haysom, who had previously worked for almost 30 years in the newspaper industry. Several changes followed. Haysom announced in January 2004 the creation of a new regional management team with the appointment of 10 Regional Directors ${ }^{5}$ to simplify the reporting structure that had previously involved regular meetings of over fifty LLSC and central LSC directors. The Regional Directors have also been given substantial powers; for example, they 'can move funding and targets around between local LSCs and their providers' (LSC 2004a:6).

This action was swiftly followed by changes to the structure of the National LSC, which, from January 2004, was organised around two directorates - Learning and Skills. Three directorates were closed down: Quality and Standards, Strategic Marketing and Operations, which led to the second major reduction in staff, particularly at the centre but also in each LLSC. The whole thrust of the reorganisation was to make the LSC 'more streamlined, manageable and responsive' (LSC, 2004b).

Our interviewees were divided over the interpretation of these changes, with strong and well-argued views being advanced for all the positions adopted. For some, the LSC still had the same vision, targets and remit, its roles had been clarified, and it was simply going through the stages of development typical of any new organisation; it had evolved, after the first few years stock had been taken, and some operations had been streamlined or rationalised.

For others (a smaller group), this was no mini-reorganisation, but the sign of dramatic and radical change to create a New $\mathrm{LSC}^{6}$, which was New with a capital $\mathrm{N}$, 'like New Labour', and which was 'leaner and meaner and faster on its feet'. This second group felt that the LSC had gone through two distinct phases of development, and, because its performance in the first two years had not lived up to the expectations of the politicians, its structure and remit had been changed to make it a more strategic planning and funding body, which no longer itself carried out the 'delivery' of education 
or training. The changes were interpreted by this group as the promotion of a business model (smaller centre, the concentration on key functions, and an annual, business planning cycle of all its activities) by Mark Haysom, who was joined in July 2004 by a new Chairman, Chris Banks, again from the private sector. Mr Banks is Chief Executive of Big Thoughts Ltd, a food and drink company.

Two elements in Richard Sennett's analysis of new structures of power in organisations fit this second interpretation: 'the discontinuous reinvention of institutions' (1998:47), which may become dysfunctional through 'downsizing'; and 'concentration without centralisation', where domination from the top increases at the same time as 'people in the lower ranks of organisations [are given] more control over their own activities' (1998:55). Later on in this article, we present evidence of the detrimental impact on local LSCs of both 'downsizing' and of increasing centralised control.

For a third group, the reorganisation was being driven by the Prime Minister's broad agenda of public service reform which, in the words of Charles Clarke, the then Secretary of State for Education and Skills, meant 'a massive devolution of decision making to front line managers and a significant reduction in the burden which diverts energy away from teaching and training' (2002:3). The new regional structure, according to Mark Haysom, was designed to create 'truly local leadership delivering local solutions to local problems' (LSC, 2004c) $)^{7}$.

These three interpretations of the structural changes to the LSC are not mutually exclusive and each contains an element of truth. One official even saw them as a combination of the first two perspectives: 'I would see it as an evolution ... with something of a step change'. For others still, the re-organisation was neither controversial nor significant.

The 10 new Regional Directors are responsible for between three and five LLSCs, but each continues to manage a local LSC as well, in order to help retain their awareness of local issues' (LSC, 2004b). With one exception among those who expressed a view, our interviewees were convinced that the balance of power had shifted away from the national office in Coventry and away from the 47 LLSCs towards the regions, and in particular towards a Management Board which has a majority of Regional Directors. One official pointed out that the new regional arrangements have no statutory basis; the regional boards are 'purely internally created advisory boards'. Others predicted that the RDAs and elected Regional Assemblies, if voted into being, would work with the 10 new Regional Directors rather than with the 47 Executive Directors of the LLSCs. A directly elected Regional Assembly was, however, overwhelmingly rejected in November, 2004 by a 78 per cent majority of voters in the North East on a turnout of 48 per cent. 
Interviewees across the sector, but particularly in the North East, also stressed the significance of the new Regional Skills Partnerships (RSP), which are to become the main mechanism for getting 'all the bits of the organisational jigsaw more closely aligned to each other'. The RSP 'will become the core accountable body' for the central agencies of the LSC, the RDA, Jobcentre Plus, the Sector Skills Councils and the Small Business Service. The plan now is for the RSP to achieve greater coherence in targets and policy among these key players, while the sub-regional level and the LLSCs are to remain the main 'delivery' mechanism. The first RSP was launched in the North East in November, 2004.

One of our interviewees raised a significant question lying behind all these structural changes, namely: 'What is the most appropriate level for assessing and responding to learning and skill needs?' In an area like the North East, which has clear-cut boundaries, a strong identity and widely shared socio-economic problems, the most logical answer - after looking at travel-to-work patterns, where, for example, people travel for almost an hour north from Darlington and south from Berwick to study and work in Newcastle - may be the region rather than the sub-region or the locality. What works for the North East may not, however, be suitable for London or the East Midlands. The follow-up questions now become: 'Does the sub-regional level work, how democratic is it and is it needed?'

Figure 1, entitled The New Landscape of Post-16 Learning: Nationally, Regionally and in one Locality, charts the new sector with its long chain of intermediaries, which has the potential to blur the lines of accountability, to drive up administrative costs and, most important of all, to confuse partners. The landscape is not only complex because it is the result of eight years of constant Government intervention and tinkering, it changes frequently as new organisations are created and others are disbanded, it requires a working knowledge of around 50 acronyms of the main organisations, and it is difficult even for professionals to negotiate. For example, there is the important distinction between Local Strategic Partnerships and Local Learning Partnerships ${ }^{8}$. Figure 1, which reveals nine levels of bureaucracy between the learning providers and learners and the main decision makers, raises questions over whether all these layers are necessary and whether they are the best way of organising learning opportunities. A number of maps or network analyses of the new Learning and Skills Sector have now been produced (eg Ecclestone, 2004). What these diagrams and figure 1 have in common is how little they reveal. Their very existence testifies to the desire of their designers to understand the complexity of the new sector and figure 1 at least has the merit of including learners who tend to be omitted from other maps. But none of them reveals very much about the dynamics of the system i.e. how the partners interact with 
one another, or what drives the system towards greater coherence and efficiency, or indeed towards increasing incoherence and inefficiency.

[Insert figure 1 about here]

The super complexity that has been built into the new arrangements also creates particular problems for dialogue and democracy. Over and above a concern about the public accountability of such bodies as the national and local Learning and Skills Councils lies a centralising trend of New Labour administrations, which leaves less and less scope for an active and democratic citizenship. Bill Williamson offered a new theory of citizenship based on Habermas's model of 'dialogue [which] is at the heart of successful learning and of a successful, open society. It is the key concept of lifelong learning' (1998:189). But what are the prospects of the three rather powerless groups of learners we have chosen to study being involved in dialogue which empowers them to engage critically, with say, the education and training they are being offered? Are any learners so empowered for that matter? As Williamson argued, 'the modern citizen has been depoliticised; the public realm of society - the realm of the political - has become so complex and removed that people neither feel involved with or able to influence the decisions taken on their behalf' (1998:202).

\section{Roles and Responsibilities}

Throughout our interviews, there was a broad agreement regarding the main functions of the LSC - that its role is to plan and to fund post-compulsory education training. Beyond this, however, interviewees talked of role accretion and confusion as the result of the increasing remit of the LSC. Role accretion manifested itself in responses to questions about its role. The list of all the tasks mentioned by interviewees runs to 39 items ${ }^{9}$ which can be grouped into 23 separate, broad roles. The main point we wish to make from interviewees' replies is that those working within the sector perceived the LSC's roles as expanding both vertically and horizontally; as one official commented: 'the LSC is suffering from priority overload'. A recent example of the continuing expansion of responsibilities is that in August 2004, the LSC took over responsibility for prison education from the Home Office.

As if that were not sufficient, the LSC is struggling to develop a new role for itself, namely, to become a major policy player at the top table, where, as one seminar participant put it, 'national policy is informed by local implementation', and where the 
remit from Government can be challenged by using feedback from the 47 local councils. The long, varied and constantly expanding list of roles, which has been given to the LSC by Government, would present a serious challenge to even the most efficient, generously staffed and stable organisation. But responding to an expanding remit with a shrinking staff (a second reduction in staffing at both national and local levels of between 30-40 per cent was announced in 2003-04) would pose huge problems for any organisation.

Role confusion, on the other hand, is the result of contradictions within policy, boundary disputes and political constraints. A particularly acute example can be seen in relation to school sixth forms and 14-19 provision. LLSCs are responsible for recurrent funding of $16-19$ education and training, though for school sixth forms this is channelled through LEAs, which still retain responsibility for capital funding. LLSCs are also asked to play a leading role in planning 14-19 provision alongside other key players. It was, therefore, no surprise that some LSC officials felt uncertain about their roles and responsibilities. As one commented, 'I categorise myself as the confused, trying to be less confused'. Role confusion also appeared to be rife between representatives of the Government Office North East, the RDA, the Regional Assembly and the LLSC. As one official remarked: 'I've been in meetings where all four of those [organisations] claim to lead on 14-19 at the present'.

\section{Relations with the DfES and Government}

York Consulting Limited was commissioned by the DfES to evaluate the new post-16 learning arrangements. In its interim report in 2003 it pointed out 'overlaps' or 'confusion' in responsibilities between the LSC, DfES, ALI, Connexions and Jobcentre Plus. In its final report in 2004, it again referred to the balance between the responsibilities of the DfES and of the LSC, asking 'whether the LSC is a strategic policy development body or whether its role is solely to implement and operationalise DfES policy' (2004:18).

In sharp contrast to these two rather anodyne evaluations, Sir Andrew Foster, in his 2004 annual report as chairman of the Bureaucracy Review Group, did not mince his words: in the view of the Group the roles of the key national organisations (DfES, LSC, ALI/OFSTED and LSDA) 'are insufficiently differentiated, and as a consequence there is overlap, inconsistency and confusion about where roles and responsibilities begin and end' (2004:8). The recommendations of the group were similarly trenchant: 'The framework contract between the DfES and the LSC should be renegotiated to give 
crystal clarity to the role of the Department and the LSC. This contract should give prime focus on strategic leadership and coherence to the DfES whilst the LSC is given the lead role in managerial implementation' (2004:4). Foster's team also argued that the excessive bureaucratic burden on providers means that 'time, energy and focus are being taken away from the primary mission of ensuring the success of learners' (2004:8).

In interviews, the relationship between the LSC, on the one hand, and the DfES, the Treasury and the Government in general, on the other, was characterised as a partnership, but a partnership of a particular kind: 'I wouldn't pretend it was a partnership of equals: it's very much a parent-child relationship. You know: "We want you to do this. We want you to do it in this way. Just go and do it"'. Other commentators from within the sector agreed that the DfES had from the very beginning imposed centralisation, based on lack of trust, on the LSC: 'What made my blood pressure rise most, not just at the beginning but throughout, was the attempted interference by the DfES at all levels ... and the number of staff they had! They didn't reduce staff by one on the formation of the LSC and it even went up. They had more people monitoring us quite often ... than we had doing it. I mean they had a parallel organisation shadowing ...' Another official made exactly the same criticism and then added: 'It's a very constraining system. It's one which has very little room for experimentation and imagination'. These perceptions are important even if the actual figures of DfES staff monitoring LSC staff are exaggerated rather than strictly accurate. The charge that the DfES could not stand back to concentrate on giving strategic leadership to the sector was not confined to LSC officials, but was also made by members of the inspectorate and of the RDAs. The charge was of meddling, of micromanagement, of establishing an 'arms length' agency and then continuing to run it. As one observer explained, we have 'an hyperactive Government which is constantly developing new initiatives and ... kind of jumps around agencies'.

Constant interference from the DfES is, however, being exacerbated by a serious conflict in policy, a conflict which is enshrined in the DfES's Five Year Strategy for Children and Learners (2004). Chapter 6 on 14-19 Education and Training expects specialist schools, colleges and training providers to form partnerships to deliver a broad and flexible choice of courses, which learners may take in a variety of places (para 33). On the other hand, Chapter 4 on Independent Specialist Schools argues that 'we will also make it easier for successful and popular specialist schools to establish their own sixth-forms, with a strong presumption in favour of their being allowed to do so in areas where there is little sixth form provision, or where there is overall low participation or attainment' (para 19). In addition, Chapter 4 announces that 
the Government, pursuing policy which emanates from the No 10 Strategy Unit, will expand the City Academies Programme to provide 200 independently managed Academies by 2010 (para 34).

So, on the one hand, LLSCs have the responsibility to develop with the appropriate providers a collaborative strategy for the transformation of all 14-19 provision in their localities. But, on the other hand, the No 10 Strategy Unit is simultaneously pressing the competitive case for more choice for some parents and some pupils and more independence for a small category of schools. For one of our interviewees, this open conflict in policy and values expressed the schizophrenia of the whole system'. It is certainly serious that New Labour now possesses not one but two Five Year Strategies; but what is worse is that they are irreconcilable. As another interviewee expressed it, the 'imposition' of a City Academy 'would blow apart the collaboration' which had taken years to build in the Learning Partnership.

It comes as no surprise that policy making in education and training is so highly politicised. This is nothing new and goes back at the very least to the days of the MSC and the introduction of the Youth Training Scheme in the hope of mopping up the sudden rise in youth unemployment. What is different now is that the remit of the LSC with regard to sixth forms and Strategic Areas Reviews (StARs) brings it up against institutional self interest, where headteachers, governors and middle class parents are very unlikely, for example, to give up their small and inefficient sixth forms without a public fight; and such resistance to managed change has immediate political repercussions both locally and nationally. The tensions between, on the one hand, an LSC, which is expected to behave like a modern business and to take quick planning decisions, and, on the other, an 'arms length' quango which has to act in concert with a broad range of partners, and which has little direct political power, are unlikely to diminish particularly in the run-up to a general election.

\section{The power to bring about change?}

An underlying theme which ran through many of the interviews was: has the LSC the power to bring about the radical and enduring change which Blunkett promised? The first 18 months of the LSC were, according to one official, 'a very trying time for everyone ... very high expectations. This is not a Government that is famous for its patience in seeing improvements in services'. The expectations of Ministers were also of a particular kind, namely that the LSC would not just transact business (eg manage contracts with training providers as the TECs used to do), but transform the culture of 
lifelong learning: to use the jargon circulating within the organisation, the LSC is supposed to be 'transformational rather than transactional', but in effect it has to fulfil both roles.

The opinion of many of our interviewees was, however, that the LSC did not have the power to bring about radical change; it was 'nibbling at the edges' rather than altering structures or reorganising provision. In the first three years of operation, the four LLSCs we are studying (two in the North East and two in London) had learned that they could close down poorly performing, work-based learning providers; that they had to tread carefully when taking action against a College with an unsatisfactory inspection report; but that 'if you dare move against a single sixth form, you've got blood on the floor'.

Despite the increase in the LSC's remit described earlier, it does not have responsibility for all types of provision within the LSS. For example, Jobcentre Plus and RDAs (through the Single Regeneration Budget) both play a major role in the provision of adult training; and higher education is the responsibility of other bodies. As one of our interviewees commented of the LSC:

'It's a very sort of thin but fat organisation, isn't it? It's very fat, it's very big and bulky with large volumes of money and learners. But it's also really quite a narrow part of the overall spectrum'.

Moreover, the LSC has to exert its power through a number of steering mechanisms which are not perceived to be as powerful by those within the organisation as they are by those outside it. One LSC official explained the position as follows:

'So for us we actually lack when it comes down to it, the levers ... formal, legal mechanisms and the funding mechanisms by which we can effect change at a very detailed level'.

LSC officials have slowly come to realise that the power of persuasion is the main type of power they can exercise: 'all you can do is try and get people to work with you. Which is when I come back to the importance of partnerships and collaborative working because it's actually the only mechanism that we've got'. The problem with this type of power is that it is dependent on credibility and on an understanding of how to make partnerships effective. Many of our interviewees, both inside and outside the LSC, pointing to its bureaucratic approach and the type of staff it had inherited, questioned 
the capacity of the organisation to effect lasting cultural change through the power of persuasion.

\section{Partnerships and relationships}

Over the last twenty years partnership has become a ubiquitous but overworked tool of Government, wherever agencies are required to work together to 'deliver' policy which Government has decided centrally. Partnership is also being endorsed by politicians and policy-makers in order to compensate for the legacy of marketisation and dysfunctional competition, which those same politicians and policy makers are responsible for. In contrast to the official view of partnership working as 'an unproblematic practice represented in idealistic fashion', Paul Warmington, Harry Daniels and their colleagues have shown how much new learning needs to take place before new professional practices are established which, for example, capitalise upon the often unacknowledged tensions between different partners (see Warmington et al, 2004:2).

The success of the LSC will, according to David Blunkett, 'depend upon strong partnerships and effective linkages with a wide range of organisations', because 'the Council cannot achieve its objectives by itself, or simply by the leverage its statutory powers and funding responsibilities might exert over others' (2000: 2 and 19). Blunkett proceeded to list no less than 22 organisations with which the LSC has to forge strong relationships and in an Annex added a further 16. Subsequent remit letters from three Secretaries of State have lengthened this formidable list by adding new bodies like the Sector Skills Councils. Officials within the LSC claim that they are not managing a market system, but 'an integrated partnership system'. Partnership is widely seen as an almost magic ingredient which will help to pull together the very large number of key players in the post-16 learning sector. Witness the view of Sir George Sweeney, the Chairman of the Bureaucracy Task Force:

'In order for the Learning and Skills Council to discharge its remit, it has to engineer cultural and relationship change through the development, at national and local levels, of genuine partnership working' (2002).

Our interviewees gave broad support to the concept of partnership, though at the same time they criticised the sheer number of partners, the costs of partnership which were 
not, they claimed, fully recognised by the DfES, and the failure to translate the production of agreed documents into change on the ground.

Some of our interviewees, however, talked of organisations which were supposed to be working harmoniously together as partners, but which were in fact openly competing for business and income. For example, there is widespread confusion and rivalry within the sector about which organisation has (or should have) responsibility for quality assurance (QA) and quality improvement. ALI inspectors argued that they should have the remit for QA, while LSC officials clearly thought that QA was their responsibility. But in the early years of the LSC there were officials working on quality issues within the DfES Standards Unit, within ALI/OFSTED and within the LSC itself with the support of the Learning and Skills Development Agency (LSDA) and the Sector Skills Development Agency (SSDA): the Quality Directorate was only abolished in the Coventry headquarters of LSC in 2003. ALI, for instance, has established both a Provider Development Unit to offer informed advice and a 'good practice' website; similar websites have also been set up by the LSC, by the LSDA and by the Standards Unit in the DfES. The Government has now intervened to create the new Quality Improvement Agency by April 2006.

Comparisons of the interviews and data from the 24 learning sites in the North East and in London suggest that partnership among the official agencies appears to be more developed in the former than in the latter. For example, officials in the North East argued that the region had been able to attract more than its fair share of Government pilot projects (such as Employer Training Pilots and the new Adult Learning Grant), because of its long reputation for effective partnership working. Another official speculated that 'we have this collaborative culture because we have such big issues to address ... [collaboration] fits very much with the psyche and the ways of working up in the North East'.

\section{Policy levers and drivers: their implications for teaching, learning and assessment}

In its initial phase, the main focus of this project has been on mapping the new learning and skills landscape. The next stage will examine the implications of this new landscape for teaching, learning and assessment (TLA) for three key groups of learners. Our aim is to look at the effects on TLA of levers and drivers that policy makers use to effect change in post-16 learning (eg planning, funding, targets, 
inspection, policy documents and initiatives). This is not to imply that there is a direct or simple relationship between Government policies and TLA. Rather, as one official put it, the LSC and its partners are concerned with 'creating an environment to enable effective teaching and learning to take place'.

Even at this early stage of the research, following initial interviews with policy makers and just one round of visits to learning sites, many possible implications for TLA are emerging. Five major levers and drivers, identified by our interviewees as having a significant impact on TLA, are briefly outlined below and will be explored later.

Planning - from April 2003, each LLSC was required to produce a Strategic Area Review (StAR) of its education and training provision. We shall study whether StARs and Three-Year Development Plans are having the desired effect of producing a higher quality and more comprehensive offer for learners.

Funding - the formation of the LSC as a unified body was, in part, a response to weaknesses in the previously separate funding systems for post-16 learning; it brought with it significant increases in funding in real terms for the post-16 sector. But has this additional funding and the new approach to funding improved the quality of education and training?

Targets - each LSC-funded provider has four 'headline targets' which it agrees with its LLSC, relating to learner numbers, employer engagement, success rates and the proportion of teachers, lecturers and trainers with professional qualifications. It also has 'floor targets' which set the minimum level of acceptable performance in terms of success rates (LSC, 2003). Over and above these targets lie another set: the Treasury's Public Service Agreement (PSA) targets for the DfES relating, for example, to Level 2 achievement, reducing the proportion of young people not in education, employment or training and increasing adult skills levels. The existence of a multitude of different targets in the learning and skills sector makes it difficult to tease out their individual effects on TLA. We will look at the interplay of targets with other factors (in particular, funding), as we seek to identify positive and negative, intended and unintended, effects on TLA.

Inspection - as well as establishing the LSC, the Learning and Skills Act 2000 also brought ALI into existence. Interviewees throughout the sector and at all levels expressed the view that inspection can have a particularly strong and immediate impact on TLA. But beneath this general consensus there is a more complex picture to explore eg teachers' and learning managers' different experiences of inspection, the costs as well as the benefits to providers and the relationship of inspection to improvement. More important still, does the current Common Inspection Framework capture all the main features of an institution, or is it possible to amass data on 
everything that can be quantified within a College or Training Centre and still fail to appreciate its underlying ethos?

Policy documents and initiatives - some of the major policy documents were listed earlier (see section on Structure, Recent Changes and Regionalisation above). These policy texts, individually and collectively, are potentially very important drivers, particularly when they are subsequently translated into a reform programme, as with Success for All, with teams of policy makers working on implementation. Two specific policy initiatives are worth singling out (from the surfeit of such initiatives which has been introduced since 1997) for their potential impact on TLA for the learners in this study - Skills for Life and Employer Training Pilots and we will work with providers to build up a detailed picture of the strengths and weaknesses of both.

\section{Where is the LSC heading?}

Our interviewees sketched three different futures for the LSC, while pointing out that history would suggest a maximum lifespan of about 8-10 years. We characterise these three futures as rationalised, regional or realigned.

A rationalised future - a number of interviewees reflected that, even after the 2003 re-organisation, anomalies and gaps existed in the newly constructed architecture and these needed to be rectified to make the landscape more coherent and less cluttered. They wished to:

- form one inspectorate from ALI and OFSTED ${ }^{10}$

- make the DfES concentrate on policy and so remove both the Standards Unit and ABSSU (Adult Basic Skills Strategy Unit) from its remit

- create one official agency with responsibility for quality assurance and quality improvement

- equalise both the unit of resource for 16-19 year olds in schools and FE Colleges and the pay structures of all professionals teaching 14-19 year olds to prevent resentments undermining hard-won partnerships

- reduce drastically the plethora of partnerships (eg strategic and learning partnerships)

- introduce a national credit accumulation and transfer scheme

- clarify responsibility for 14-19 year olds now that a new policy phase of 1419 has been created since the LSC was established with a remit which begins at age 16 . 
One official also wanted evolutionary change from 'the bureaucratic overkill [used] in establishing the new accountability arrangements' to a system 'where in five years' time providers are much more in charge of their own destiny', responsible for their own quality assurance and quality improvement, 'a sort of lighter touch inspection'. These views are in close accord with those of the Bureaucracy Task Force which in its final report recommended self-regulation, based on 'intelligent accountability' and a 'trust relationship' with all providers (2004:6).

A regional future - almost all our interviewees were agreed that the regional dimension would in future be far more prominent, but they disagreed about the possibility of further large-scale reorganisation in the regions. Some thought that the LLSCs would disappear into the RDAs or into Regional Assemblies in the next five to seven years. Others, from an LSC background were unconvinced, and one commentator predicted that the sector is more likely to end up with 'a classic British compromise', where a national LSC with a strong regional structure will be closely scrutinised by elected Regional Assemblies. We noted one significant difference between our northern and southern samples: discussions of possible regional futures were more active in the North East than in London and appeared more likely to interviewees there, partly because of the greater experience of regional partnership in the former, and partly we think because the interviews were held in the run-up to the elections for a Regional Assembly in the North East.

A realigned future - one official speculated about a further realignment such as the LSC splitting into two separate Councils: 'There's a logic to a 14-19 Funding Council ... and a 19+ Council which might incorporate higher education'. In this scenario, two councils emerge: a 14 -19 Learning Council and an Adult Learning Council.

It is worthy of note that none of our well-placed interviewees suggested that a period of consolidation was likely. Constant change, particularly of structures, has become the recurrent disease of English vocational education and training.

\section{Conclusion: achievements and challenges}

This paper has focused on the role of the LSC, its interaction with other key partners in the learning and skills sector and its use of steering mechanisms to drive policy and bring about change. We have described both the amount of internal change the LSC has experienced in its first years and the pace of external change to which it has had to respond. As a result of their survey, undertaken in 2002-3, of 16 local LSCs to assess the early progress of the LSC, Ramsden et al concluded that 
'as yet, very little has changed since the establishment of the LSC ... greater national coherence and centralisation has (sic) been achieved at the expense of local flexibility ... development of these [local] partnership bodies is patchy, often ineffective and lack of funds impedes their ability to influence policy ... [and] there is little evidence to suggest that provision under the LSC is any more demand-led than under previous structures ...' (2004:416-7).

In our view, perhaps the most significant achievement of the LSC so far is that the need for a more unified and integrated set of learning arrangements and even a learning and skills sector is now widely acknowledged. To date we have interviewed no-one who has argued for a return to the previous arrangements. The LSC has also brought parts of the post-16 landscape into full view for the first time, for example, Adult and Community Education. It is still, however, only a partially unified structure with limited scope within an incompletely reformed learning and skills landscape, which retains some fundamental features of the previous voluntarist, divided and marketised arrangements. The complexity of the sector has been exposed for all to see, that complexity now has to be managed, but the complexity has also been increased by the partial nature of recent reforms. The challenge now is to simplify that landscape and to turn what is still a loose, confusing and diverse sector into a more coherent, unified and integrated system for supporting lifelong learning.

In this partially reformed climate, a number of deep tensions remain. The LSC is expected, for example, to cope with all the contradictions and strains caused by responding simultaneously to the following potentially conflicting forces: it must be a centralising Council in order to create more consistency round the country, and yet it must allow more local flexibility to cater sensitively for differing needs; the previous heavy emphasis on competition is now to be tempered with more collaboration and partnership working; it is charged by Government with fostering both economic prosperity and social inclusion; it needs to balance market forces with the need for regulation; it is under pressure from Government to 'deliver' both excellence and equity; it is responsible for planning coherent educational provision for all 14-19 year olds and yet must somehow accommodate the individual requirements of independent, specialist schools and City Academies; it is being urged to become more transformational and less transactional, to move from managing contracts to managing a sector; it must reconcile as best it can the values of the labour market with those of the educational system; and it is operating a business model, while being criticised for not being publicly accountable. It is a tall order. 
Within activity theory internal tensions are treated as the engines of change. Engeström, for instance, emphasises both the need for 'constructive controversy' in developing new partnerships and the central role of contradictions and dialogue in the creation of new knowledge: in his own words, activity theory testifies to 'the importance of critical questioning and the rejection of the accepted wisdom as a triggering action in innovative learning' (1999:397). This approach argues then, for an atmosphere which positively encourages principled disagreement and dissent within the sector rather than command and control, if indeed the sector of post-16 learning is to exhibit continuous improvement and if it is to show evidence of being itself capable of learning.

Our evidence so far suggests that the LSC is neither a partnership organisation nor a business enterprise but a new, complex hybrid which could be characterised as a 'centralised but regionally and locally focussed, market-oriented but heavily regulated, non-departmental but departmentally-driven, public body which has to work with independent institutions to create new partnerships in order to bring the supply and demand for learning and skills into closer alignment'.

The LSS as a whole is also having to cope with wave upon wave of change, and, as York Consulting Ltd point out, (2003:100), there has been change of three main kinds: in policy (eg a new Skills Strategy and a new Strategy for reform of FE), in organisations (eg new agencies such as LSC, ALI, QIA ${ }^{11}$ and Connexions), and in operations (eg Provider Performance Review and 3 year Development plans). The sector will be stretched to the limits to respond to these different types and levels of change. Can it also put 'teaching, training and learning at the heart of what we do', as Success for All (2003b:24) has required? We hope to answer that question in our next article. $^{12}$

\section{References}

Ainley, P (1998) Towards a learning or a certified society? Contradictions in the New Labour modernization of lifelong learning. Journal of Education Policy, 13, 559-573.

Ainley, P (2000) Missing the point about the Learning and Skills Council, a comment on Coffield, Journal of Education Policy, 15, 5, 585-588.

Bernstein, B (1996) Pedagogy, symbolic control and identity: theory, research, critique (London: Taylor \& Francis)

Blunkett, D (2000) Remit Letter to Learning and Skills Council (London: DfES)

Bureaucracy Review Group (2004) Annual Report (London: DfES)

Bureaucracy Task Force (2004) Extending Trust (Coventry: LSC)

Clarke, C (2002) Foreword to Success for All: Reforming Further Education and Training (London: DfES)

Clarke, J and Newman, J (1997) The Managerial State (London: Sage)

Department for Education and Employment (1996) Lifetime Learning: a policy framework (London: DfEE)

Department for Education and Employment (1998) The Learning Age: A Renaissance for a New Britain (London: DfEE)

Department for Education and Employment (1999) Learning to Succeed: a new framework for post-16 learning (London: Stationery Office, $\mathrm{Cm}$ 4392)

Department for Education and Employment (2001) Skills for Life: The National Strategy for Improving Adult Literacy and Numeracy Skills (Nottingham: DfEE)

Department for Education and Skills (2002a) 14-19: Extending Opportunities, Raising Standards (London: Stationery Office, Cm5342) 
Department for Education and Skills (2002b) Success for All: Reforming further Education and Training (London: DfES)

Department for Education and Skills (2003a) The Future of Higher Education (London: Stationery Office, Cm5735)

Department for Education and Skills (2003b) 14-19: Opportunity and Excellence (Norwich: HMSO)

Department for Education and Skills (2004) Five Year Strategy for Children and Learners (London: DfES, $\mathrm{Cm}$ 6272)

Ecclestone, K (2004) "Mapping the Post-16 Landscape", Teaching and Learning, Newsletter of the ESRC's TLRP Programme, Post Compulsory Edition, May.

Engestrőm, Y (1999) "Innovative learning in work teams: Analyzing cycles of knowledge creation in practice", in Engestrőm, Y, Miettinen, R and Punamaki, R-L (eds) Perspectives on Activity Theory (Cambridge: Cambridge University Press) 377-404.

Felstead, A and Unwin, L (2001) "Funding Post Compulsory Education and Training: a retrospective analysis of the TEC and FEFC Systems and their impact on skills", Journal of Education and Work, $14,1,91-111$

Fullick, L (2004) Adult learners in a brave new world: Lifelong Learning Policy and structural changes since 1997 (Leicester: NIACE)

Haysom, M., (2004), Speech to BCC Conference, 26 February 2004, http://www.Isc.gov.uk/National/Media/Speeches/LatestSpeeches/mhbcc26feb04.htm.

HMT (2003) Every Child Matters (London: The Stationery Office, Cm 5860)

Labour Party (1996a) Lifelong Learning (London: Labour Party)

Labour Party (1996b) Learn As You Earn: Labour's Plans for a Skills Revolution (London: Labour Party)

Last, G (2004) 'Personalised Learning: adding value to the learning journey through the primary school' (London: DfES)

Leadbeater, C (2004) Personalisation through participation: a new script for public services (London: Demos)

LSC (2003), Learning and Skills Council Meeting Briefing No. 27, December 2003, http://www.Isc.gov.uk/National/Documents/Series/CouncilMeetingBriefings/default.htm.

LSC (2004a) Concordat on Future Working between the Regional Development Agencies and the Learning and Skills Council, July (Coventry: LSC)

LSC (2004b) The Learning and Skills Council announces a new regional management structure, Press Release, 7 January 2004 (Coventry: LSC)

LSC (2004c) New Regional Structure unveiled to help LSC meet local needs, Press Release, 4 February 2004 (Coventry: LSC)

Newman, J (2000) 'Beyond the New Public Management? Modernising Public Services' in Clarke, J., Gerwitz, S. and McLaughlin, E. New Managerialism, New Welfare? (London Sage/Open University)

Pollard, A and James, M (eds) (2004) Personalised Learning: A Commentary by the Teaching and Learning Research Programme (Swindon: ESRC)

Ramsden, M, Bennett, R and Fuller, C (2004) The Learning and Skills Council and the Institutional Framework for Post-16 Education and Training: an initial assessment, Journal of Education and Work, $17,4,397-420$

Ramsden, M, Bennett, RJ and Fuller, C (2004) "Short-term Policy and the Changing Institutional Landscape of Post- 6 Education and Training: the case of learning partnerships in England, Scotland and Wales", Journal of Education and Work, 17, 2, 139-165

Sarason, S.B. (1990) The Predictable Failure of Educational Reform: Can We Change Course Before It's Too Late?, San Francisco: Jossey-Bass

Skelcher, C (1998) The Appointed State (Buckingham: Open University Press)

Sennett, R (1998) The Corrosion of Character: The Personal Consequences of Work in the New Capitalism (New York: W.W. Norton)

Sweeney, Sir George (2002) Trust in the Future, First Report from the Bureaucracy Task Force (Coventry: LSC)

Tabor, A (2004) The TEC Experience: An overview, with lessons from the transition from Training and Enterprise Councils to LSC (Sheffield: DfES)

Warmington, P, Daniels, H, Edward, A, Leadbetter, J, Martin, D, Brown, S and Middleton, D (2004) "Learning in and for interagency working: conceptual tensions in 'joined up' practice", Paper presented at TLRP Conference, Cardiff, November

Williamson, B (1998) Lifeworlds and Learning: essays in the theory, philosophy and practice of lifelong learning (Leicester: NIACE)

Working Group on 14-19 Reform (2004) 14-19 Curriculum and Qualifications Reform: Interim Report of the Working Group on 14-19 Reform (Nottingham: DfES)

York Consulting Ltd (2003) Evaluation of Post-16 Learning Arrangements, Interim Report, London: DfES, Research Report No 435

York Consulting Ltd (2004) Evaluation of Post-16 Learning Arrangements, Final Report, London: DfES, Research Report No 542. 
It is no longer possible to separate completely the two worlds of FE and HE and certain forms of HE are eligible for funding from the LSC, as Pat Ainley has pointed out (2000:587). The researchers wish to acknowledge the funding of this project by the ESRC - reference number RES-139-250105 A fuller version of this paper is being written by Ann Hodgson, Ken Spours, Frank Coffield, Richard Steer, lan Finlay, Sheila Edward and Maggie Gregson and will be available from any of the authors from May, 2005. The Millennium Dome was a prestige project funded by the New Labour government to celebrate the year 2000. It has become a byword for profligate government expenditure. The 10 regional directors include two for London.

Soon after his appointment as Chief Executive, Mark Haysom presented a paper to the Council's members on his vision for 'The New LSC' (LSC, 2003) and he subsequently talked about 'the new LSC' (no longer with a capital ' $n$ ') in an address to the British Chambers of Commerce in February 2004 (Haysom, 2004). Increasingly over the last two years, the New Labour Government has been employing the concept of 'personalisation', which is likely to become the organising principle for the reform of the public services, in health and the criminal justice system as well as in education. One of its leading advocates, Charles Leadbeater, explains the challenge of personalisation as the shift from 'a model in which the centre controls, initiates, plans, instructs and serves, to one in which the centre governs through promoting collaborative, critical and honest selfevaluation and self-improvement' (2004:90). In September 2004, the DfES explained how personalisation should not be equated with individualisation by listing its five key components: assessment for learning, teaching and learning strategies, curriculum entitlement and choice, a student-centred approach to school organisation and strong partnerships beyond school (Last, 2004). The Teaching and Learning Research Programme then issued a commentary on personalised learning, asking, inter alia, 'Is this initiative really about learning? Or is it, despite the title, still primarily about teaching and curriculum delivery?' (Pollard and James, 2004:24).

According to Ramsden, Bennett and Fuller (2004:142), learning partnerships "are an initiative begun in 1998 that seeks to bring local partners together in a process of discussion and joint planning of provision of post-16 education and training". Since April 2003 LLSCs can choose whether or not to fund learning partnerships and most have become the learning arm of local strategic partnerships. The latter were formed in 2001 to bring together into one forum a wide range of public, private, community and voluntary sector organisations to create a Community Strategy and a Local Neighbourhood Renewal Strategy. Typically, a local strategic partnership covers such themes as Health, Housing, Transport, Crime etc as well as Learning.

All the roles mentioned by interviewees in the first 49 interviews to be analysed are listed here:

1. to promote the benefits of education and training; a statutory duty

2. to make the case for funding

3. to establish and run government initiatives

4. to introduce structural reforms

5. to plan and fund $16+$ learning, but also increasingly $14-19$

6. to become more demand led, to improve productivity

7. to improve social inclusion through improved employability

8. to police, monitor, vilify and criticise the sector

9. to encourage and fund improvement in organisations

10. to understand the needs of local areas

11. to challenge the received wisdom of the government and to become policy experts

12. to get the post 16 sector to feel like a system "rather than a series of individual fiefdoms"

13. to realign the Education and Training sector with the needs of the local economy

14. to reorganise the provision of 14-19 year old

15. to create national consistency in policy and funding, while allowing for local flexibility

16. to buy good quality provision and to weed out bad

17. to create transformational rather than transactional change

18. to change the culture of LLL

19. to bring employers on board more than previously

20. to play a QA role in Colleges after inspection

21. to work through partnerships and relationships as a means of creating change

22. to focus on medium and long-term transformation rather than short-term transaction

23. to have the right pattern of learning available (in the sub-region) to meet the needs of individuals, communities and employers

24. to take a strategic look at all post 16 learning, including quality as well as quantity, physical infrastructure, location etc

25. to assume responsibility for school sixth forms (from April 2002)

26. to use strategic area reviews to plan provision

27. to produce policy and strategy for adult and community learning

28. to produce policy and strategy for workforce development

29. to produce national strategies and local plans which dovetail

30. to act as a broker between the purchaser and supplier of skills

31. to tackle the long-standing, comparative underperformance of UK in participation of young people post 16 in education and training 
32. to understand the demand side and to ensure via structural reforms that the supply side responds

33. to use the best information and intelligence

34. to play a governance role at local level, bringing together disparate and conflicting needs

35. to provide strong leadership for the post 16 sector

36 . to bring coherence to a very fragmented system

37. to share best practice among learning providers

38. to engage more young people and adults in learning

39. to bring all the partners together to make all of the above happen

As this article was being finalised in March, 2005 came news that OFSTED and ALI are to amalgamate. Agencies come and go with the same frequency of football managers.

The Quality Improvement Agency (QIA) will replace the Learning and Skills Development Agency and that is the second agency to be restructured during the writing of this article. The Progress Report on the establishment of the new agency contains the request from providers for the QIA to supply 'how to' manuals on self assessment. (www.successforall.gov.uk/index.cfm?pg=104,March2005)

We wish to thank the two anonymous referees whose perceptive and detailed comments on an earlier version of this article helped to improve it. 